\title{
А.В. Петрук*
}

\section{«УВЛЕЧЕННЫЙ СТРАСТЬЮ К ИССЛЕДОВАНИЯМ»: ЖИЗНЬ И ДЕЯТЕЛЬНОСТЬ В.К. АРСЕНЬЕВА В ОБЩЕСТВЕННОМ И НАУЧНОМ ДИСКУРСЕ}

\begin{abstract}
В статье анализируется комплекс публикаций, специально посвященных жизни и деятельности В.К. Арсеньева, которые увидели свет в XX - начале XXI вв. Автор прослеживает, как неоднозначно в разные годы транслировался образ В.К. Арсеньева в общественном и научном дискурсе, как интерпретировались детали биографии, оценивался его вклад в изучение и развитие региона, особенности художественного стиля и др.
\end{abstract}

Ключевые слова: В.К. Арсеньев, региональные исследования, общественный дискурс, научный дискурс

«Guided by the passion for research»: life and work of Vladimir Arseniev in public and scientific discourse. ANZHELIKA V. PETRUK (Vladimir K. Arseniev Museum of Far East History)

The article analyzes a series of publications specifically devoted to the life and work of Vladimir Arseniev, which came out of print in the $\mathrm{XX}^{\text {th }}-$ early $\mathrm{XXI}^{\text {st }}$ century. The author traces how ambiguously the image of the famous explorer was shaped in the public and scientific discourse, how the details of his biography were interpreted, his contribution to the study and development of the region, features of his artistic style were assessed depending on the ideology and political context of the time.

Keywords: V.K. Arseniev, regional studies, public discourse, scientific discourse

Биографии «великих» открывают людям широкие возможности для самопознания. Л.П. Репина, один из основоположников концепции интеллектуальной истории, образно сформулировала эту особенность жанра: «Биографии известных людей ...всегда служат своеобразным зеркалом, глядя в которое читатель может многое узнать о себе» [23, с. 6]. В этом смысле большой интерес представляет жизнь и деятельность В.К. Арсеньева - путешественника, исследователя, писателя, которому выпало жить и работать на стыке эпох и с чьим именем связывают преемственность дальневосточной науки - от традиций Русского географического общества до нового советского краеведения. Цель данной статьи - проследить, как неоднозначно в разные годы транслировался образ В.К. Арсеньева в общественном и научном дискурсе: положительно в общем контексте, однако по-разному в деталях - в зависимости от идеологических установок и политической ситуации в стране.

Два небольших рассказа, главным действующим лицом которых является В.К. Ар-

* ПЕТРУК Анжелика Витальевна, заместитель директора по научной работе Музея истории Дальнего Востока им. В.К. Арсеньева.

E-mail: anzhelika07@list.ru

(C) Петрук А.В., 2020 
сеньев, были опубликованы еще при его жизни: это написанные участниками его походов И.А. Дзюлем и П.П. Бордаковым воспоминания о совместных путешествиях, где авторы дают характеристику В.К. Арсеньеву, описывая его каждодневную работу в экспедиции. Рассказ И.А. Дзюля «В тайге» увидел свет в 1910 г. на страницах петербургского журнала «Наша охота» [10], а эссе П.П. Бордакова «На побережье Японского моря» было опубликовано в 1914 г. в нескольких номерах журнала «Юная Россия» [5].

Публикации об Арсеньеве, вышедшие в первое десятилетие после смерти исследователя, за исключением некролога в газете «Красное знамя», носили преимущественно негативный оттенок. В канун первой годовщины его ухода, в 1931 г. главная региональная газета выпустила статью некоего Г. Ефимова под заголовком «Арсеньев как выразитель идеи великодержавного шовинизма» [13]. Автор, конечно, скрыл свое имя под псевдонимом, но здесь важно другое: он выразил мнение редакции, а в целом - и «всего советского народа», как писали в те годы. Автор статьи упрекал Арсеньева в том, что тот якобы пытался протащить свое «мелкобуржуазное мировоззрение» в новую пролетарскую науку. Его выставили врагом трудового народа, припомнив его негативное отношение к китайским отходникам, которые проживали в крае нелегально и, как считал Арсеньев, занимались грабежом и разбоем, расхищали природные ресурсы тайги, нещадно при этом эксплуатируя коренное население региона.

Примерно в это же время, в начале 1930-х гг., готовилась к публикации первая официальная биография В.К. Арсеньева, составленная профессором Московского университета Ф.Ф. Аристовым. Стоит сожалеть о том, что это исследование так и не увидело свет. Аристов, знавший Арсеньева лично и состоявший с ним в многолетней переписке, к 1930 г. написал пространный биографический очерк, который готовил к изданию в виде отдельной книги. Изначально он планировал поместить эту биографию в свой труд «Русские путешественники - исследователи Азии», и в письмах всячески мотивировал Арсеньева написать подробную автобиографию. Судя по материалам их переписки, сохранившейся в архиве Общества изучения Амурского края (Архив Общества изучения Амурского края, далее - АОИАК. Ф. 14. Оп. 3. Д. 5), уже в 1929 г. Арсеньев выразил согласие выслать материалы, которые Аристов планировал использовать для написания очерка, приуроченного к празднованию 30-летия деятельности Арсеньева на Дальнем Востоке. Этот очерк был положен в основу вступительной статьи к десятитомному собранию сочинений В.К. Арсеньева, которое в конце 1920-х гг. готовилось к публикации в издательстве «Молодая гвардия» (АОИАК. Ф. 14. ОП. 3. Д. 5. Л. 1). Издание так и не состоялось, а сам очерк в сокращенном виде под названием «Владимир Клавдиевич Арсеньев (Уссурийский)» увидел свет на страницах журнала «Землеведение» уже после смерти Арсеньева [3]. Как следует из переписки, Арсеньев изначально был против приставки к своей фамилии. Аристов настаивал, утверждая, что таким образом будет легче наводить справки о нем в словарях и энциклопедиях. К тому же, если есть Семенов-Тянь-Шанский, почему бы не быть Арсеньеву-Уссурийскому?

Никаких предположений о том, почему так и не увидел свет этот большой очерк, не высказывают ни дочь профессора Татьяна Аристова, которая на протяжении нескольких лет работала с наследием отца [4], ни А.И. Тарасова - один из ведущих арсениеведов XX в. С комментариями Тарасовой очерк Аристова был опубликован в журнале «Дальний Восток» в 1974 г. [30]. Ссылаясь на переписку Аристова с Арсеньевым, а позднее - с его женой Маргаритой Николаевной, Тарасова упоминает о том, что Аристов работал очень спешно, его торопили из издательства, даже не оставили времени на то, чтобы перепечатать рукопись на машинке. Поэтому очерк вышел «сырой», и он сам просил редактора не ставить его авторскую подпись, а лишь обозначить, что вступительная статья составлена «на основании материалов, имеющихся у Ф.Ф. Аристова» [30, с. 124]. Таким образом, к 1930 г. задуманный Аристовым пространный очерк не был готов к публикации. А внезапный уход Арсеньева из жизни сделал невозможным, или, по крайней мере, значительно отодвинул во времени издание его трудов. Двумя годами позднее не стало и самого Аристова. Рукописный вариант очерка, несмотря на предпринятые Татьяной Аристовой попытки его разыскать, затерялся. Однако даже в таком виде, в каком очерк появился на страницах журнала «Землеведение», он может считаться первой опубликованной биографией В.К. Арсеньева.

Очерк носит описательный характер, автор много внимания уделил детству и отрочеству 
Арсеньева, в ущерб описанию его экспедиционного опыта: экспедиции на Сихотэ-Алинь лишь упомянуты, «секретные» экспедиции 19111913 гг. поданы как походы за сбором археологических артефактов. К тому же, повествование о жизни Арсеньева обрывается на 1924 г. Вероятно, автор доработал бы свой очерк, если бы издательство заявило о намерении выпустить десятитомник сочинений Арсеньева, хотя бы и посмертно. Однако в обстановке начала 1930-х гг. это было уже вряд ли возможно. В стране началось наступление на классическое краеведение, которое завершилось полным его разгромом в годы «большого террора». В.К. Арсеньева к тому времени уже не было в живых, но его имя прочно увязали с термином «великодержавный шовинизм». Именно в таком контексте он упоминается в статье «За большевистскую бдительность в краеведении», опубликованной в 1932 г. в первом номере журнала «Советское краеведение». Скрываясь за псевдонимом «Г.В.», автор статьи клеймит тех, кто занимается изучением региональной истории без оглядки на постановления X пленума Центрального бюро краеведения, в резолюции которого отмечалась необходимость «вести решительную борьбу с проникновением в советское краеведение великодержавного шовинизма как классово враждебной идеологии» [8]. В числе тех, кого стоило «беспощадно разоблачать», упомянут и Арсеньев: «Шовинистический душок имелся и у покойного исследователя Никольск-Уссурийского края В.Н. Арсеньева (“Дерсу Узала”, "Гольды”, “Орочи” и др.)» [8]. В публикации перепутаны инициалы и неверно названы работы Арсеньева, но речь идет именно о нем, и, что важно, упоминание его имени в таком контексте исключало в те годы всякую возможность публикации его трудов. Таким образом, запланированное в 1930-х гг. издание не состоялось, и очерк, написанный Ф.Ф. Аристовым, не увидел свет. Поэтому публикация в журнале «Землеведение» - единственная написанная при его участии биография В.К. Арсеньева, изданная в предвоенные годы.

Первые серьезные исследования о жизни и деятельности В.К. Арсеньева появились во второй половине 1940-х гг., когда на волне разбуженного войной патриотизма, с разрешения властей, в прессе стали публиковаться статьи о знаменитых путешественниках, выдающихся деятелях науки, начинавших свой путь еще в царской России. Им «простили» их дорево- люционный опыт, а в отношении некоторых, в том числе Арсеньева, даже выдвинутые ранее обвинения в шпионаже и контрреволюционной деятельности. В 1945 г., по решению Приморского крайисполкома, имя В.К. Арсеньева было присвоено краевому музею и улице Производственной (бывшей Федоровской), на которой, в доме № 7, знаменитый путешественник провел последние годы своей жизни. В 1947 г., в канун 75-летия со дня рождения В.К. Арсеньева, состоялись две большие публикации: одна - в центральном издательстве [14], а другая - в дальневосточном[24].

Н. Рогаль в историко-биографическом очерке об Арсеньеве не приводит никаких данных о его детстве, семье, учебе и начале службы, но в его книге есть попытка оценить деятельность Арсеньева по исследованию Дальнего Востока в контексте времени: автор подчеркивает слабую изученность Уссурийского края к началу $\mathrm{XX}$ в. и описывает вклад Арсеньева в расширение знаний о регионе. Очевидно влияние на автора господствующей идеологии: всячески стремясь показать преимущества советской системы над политико-экономическим устройством царской России, он даже случившиеся в экспедициях голодовки представляет следствием нерасторопности и халатности тогдашних властей. Так, описывая благополучный выход путешественников к питательной базе в 1927 г., и вспоминая в связи с этим голодовку Арсеньева и его спутников на реке Хуту в экспедиции 1908-1910гг., он подчеркивает: «Разве мог Арсеньев чувствовать себя так же защищенным при царской власти?» [24, с. 43]. Отдавая должное экспедиционному опыту Арсеньева, подчеркивая его роль в развитии музейного дела на Дальнем Востоке, автор, однако, указывает на идеологическую недальновидность исследователя, обвиняя его в неверной оценке перспектив экономического развития региона, в недоверии к новым формам организации труда (колхозному строительству и применению новой техники). Считая этнографию ареной классовой борьбы, Рогаль также упоминает об ошибках Арсеньева в оценке положения инородцев. Упоминая экспедиции по выселению незаконно проживающих в тайге китайцев, он признает научное значение собранных Арсеньевым материалов, однако считает, что Арсеньев «...был в плену официальной буржуазной точки зрения на т.н. “восточный вопрос", толковал о желтой опасности...» [24, с. 30]. Смещая акценты, автор 
сочувствует проживающим в тайге китайцам и говорит о жестокой эксплуатации их русскими капиталистами-промысловиками, не признавая при этом повсеместного ограбления коренного населения китайскими отходниками. Оценивая Арсеньева как писателя, Рогаль утверждает, что именно одобрительное письмо М. Горького в 1928 г. побудило исследователя к художественному переосмыслению своих дневниковых записей. При этом автор игнорирует тот факт, что к 1917 г. уже были написаны «Дерсу Узала» и «По Уссурийскому краю». Весьма оригинально, но вполне в духе времени он трактует это в своем исследовании: «Решающую роль сыграло появление нового демократического читателя, которому исследователь почел себя обязанным рассказать о всем виденном и на признание которого он тоже мог рассчитывать. Не случайно рубежом, когда окончательно определилось его литературное призвание, стал 1917 - год Великой Октябрьской социалистической революции» [24, с. 55]. Автор восторгается образностью речи Арсеньева, но при этом указывает на его «классовую ограниченность», на «узость рамок», упрекая исследователя в том, что тот не выходит за пределы тайги и игнорирует позитивные изменения, происходящие в городах при новой власти, не затрагивает в своих произведениях острых социальных вопросов. Странно предъявлять такие обвинения писателю, который позиционировал себя как натуралист и в своих книгах всего лишь пытался обобщить свой экспедиционный опыт. Однако подобная критика была вполне в духе времени, когда любое художественное произведение проверяли на лояльность власти и препарировали с точки зрения его соответствия принципам пролетарского интернационализма. Все же Н. Рогаль провел большую работу, привлекая, помимо ранее опубликованных, материалы из Государственного архива Хабаровского края и Хабаровского музея им. Н.И. Гродекова. Он подвел итог экспедиционной и научной деятельности Арсеньева, впервые оценив его вклад в изучение Дальнего Востока.

В послевоенные годы во Владивостоке состоялось первое системное издание трудов В.К. Арсеньева: шеститомное собрание сочинений, в которое вошли не только художественные произведения, но и некоторые статьи, научные доклады и другие материалы из наследия известного путешественника. Большую работу по подготовке этого издания провел друг Арсенье- ва, участник одной из его экспедиций, Николай Кабанов. Благодаря его усилиям справочный аппарат издания пополнился списком работ Арсеньева, публикаций о нем, а также описанием архива исследователя из собрания Приморского филиала географического общества. Опыт по работе с наследием В.К. Арсеньева пригодился Кабанову в написании собственного труда книги о жизни и деятельности В.К. Арсеньева. Поскольку автор был лично знаком со своим героем, книга получилась живая и интересная. Кабанов излагает и мотив написания своего исследования: в 1945 г., в год 15-летия со дня смерти В.К. Арсеньева, по инициативе научных организаций Приморского и Хабаровского краев было решено создать биографический очерк и «на примере его жизни и работ показать, что богатства природы Дальнего Востока ждут и будут еще ждать новых людей для их освоения» $[14$, с. 5].

Опираясь на документы из архива Приморского отделения географического общества и на свой личный опыт общения с В.К. Арсеньевым, Кабанов приводит интересные сведения о его жизни и деятельности. Автор первым предпринял попытку систематизировать наследие Арсеньева, описывая его вклад в науку по отраслям: краеведение, флора и фауна, археология и история, этнография и т.д. Как и Рогаль, Кабанов не свободен от идеологических штампов. Отмечая вклад Арсеньева в изучение быта и культуры коренных народов Дальнего Востока, он считает его описание «статическим», а политические суждения - ошибочными. И в связи с этим утверждает, что Арсеньев не смог разглядеть политические и социальные сдвиги, которые произошли после революции в жизни коренного населения региона. Даже перевод книги «В дебрях Уссурийского края» на немецкий язык (издание 1923 г.) автор трактует в духе времени: «...Немецкая агентура познакомилась не столько с интересной книгой Арсеньева, сколько с вожделенным для них участком богатого Приморья» [14, с. 62]. На страницах своей книги Кабанов даже утверждает, что Арсеньев помогал партизанам в годы гражданской войны: «...В период белогвардейского разгула в Приморье ..., когда отряды красных партизан принуждены были временно отходить в тайгу, Арсеньев снабдил их командование картами и планами районов пребывания отрядов партизан и войск противника (японцев)» [14, с. 21]. Вероятно, за этим утверждением скрывалась 
попытка автора доказать лояльность Арсеньева к новой власти, т.к. в других источниках этот факт не упоминается. Кабанов, как участник одной из экспедиций Арсеньева, отводит значительное место в своей книге описанию его путешествий. Ошибочно относя встречу Арсеньева с Дерсу к 1902 г., он все же довольно подробно описывает экспедиции 1906-1910 гг., поездку на Камчатку в 1918 г. и экспедицию 1927 г. по маршруту Советская Гавань-Хабаровск, в которой сам принимал участие в качестве геоботаника. И еще одно важное достижение автора: в своем исследовании он дает классификацию литературных трудов Арсеньева, разделив их на три группы: работы общегеографического и краеведческого характера, специальные исследования, литературно-художественные труды [14, с. 38].

Особую страницу в работе с наследием В.К. Арсеньева открыл ученый-фольклорист Марк Азадовский, который впервые предпринял попытку дать научный анализ его литературного творчества. Книга «В.К. Арсеньев - путешественник и писатель. Опыт характеристики» вышла в свет в Чите в 1955 г. [1]. В предисловии к изданию литературовед Е. Петряев пишет о том, что книга знаменует 25-летний юбилей ухода Арсеньева из жизни. Азадовский, знавший Арсеньева лично, собрал коллекцию неопубликованных материалов и писем Арсеньева, и готовил их к публикации в своем исследовании. Однако смерть ученого в 1954 г. помешала изданию его труда, и книга вышла через год, незаконченной - в том виде, в каком ее успел подготовить автор [1, с. 3].

В своей книге Азадовский много внимания уделяет исследовательскому методу Арсеньева, считает его последователем Пржевальского и Семенова-Тянь-Шанского, которые выступали за комплексный подход к изучению новых территорий [1, с. 9]. Азадовский принимал участие в работе этнографического кружка, созданного Арсеньевым при Хабаровском музее в 1913 г. Он приехал в Хабаровск с целью собрать фольклорный материал в славянских селах Приамурья, и Арсеньев не только всячески поддерживал его в работе, но и стремился помочь в публикации результатов этого исследования [20, с. 84-90]. В конце 1914 г. Азадовский уже вернулся в столицу, но продолжал общаться с Арсеньевым, поддерживая переписку. Молодой коллега был в числе тех, кому Арсеньев отправил в дар свою первую книгу, изданную в Ха- баровске в 1914 г., - «Китайцы в Уссурийском крае», и Азадовский в своем исследовании дает этой книге очень высокую оценку. Он видит ее ценность в том, что первая глава «Китайцев» представляет собой краткое изложение первой главы «Краткого военно-географического и военно-статистического очерка Уссурийского края», опубликованного в 1911 г. штабом Приамурского военного округа под грифом «секретно», следовательно - недоступного широкому читателю. Поэтому «Китайцы», по мнению Азадовского, стали первым изданием, в котором содержались и предъявлялись публике систематизированные сведения о флоре и фауне Приморья.

На страницах своей книги Азадовский спорит с Кабановым и другими исследователями творчества Арсеньева, которые утверждали, что Владимир Клавдиевич нашел свой литературный стиль только после того, как получил одобрительное письмо Горького. Опираясь на личную переписку и ссылаясь на дневники Арсеньева, Азадовский утверждает, что обе книги - «По Уссурийскому краю» и «Дерсу Узала» - были написаны Арсеньевым гораздо раньше, в 1916 г., и только дефицит бумаги стал препятствием к их публикации [1, с. 40]. Будучи профессиональным литературоведом, Азадовский анализирует особенности литературного языка Арсеньева. Он считает, что основные черты арсеньевского стиля проявились в его наиболее раннем произведении «Отчете о деятельности Владивостокского общества любителей охоты», опубликованном в 1905 г. В этой публикации, считает автор, уже видна творческая манера Арсеньева - сочетание исследователя и художника. Приводя большие фрагменты из этой работы, Азадовский обращает внимание на подробность описания, внимание автора к деталям (например, в характеристике двух видов промышленников), и в то же время - на богатство образов в описании природы, метафоричность языка, как, например, в отрывке, условно озаглавленном «Стон тайги» [1]. Азадовский утверждает, что Арсеньева необоснованно упрекали в «таежном романтизме», что он был реалистом, и, изучая и описывая тайгу в деталях, всячески стремился обратить это новое знание на пользу людям [1, с. 68].

Одновременно с книгой М. Азадовского в серии «Замечательные географы и путешественники» вышла небольшая брошюра Г.В. Карпова 
«В.К. Арсеньев» [15]. Она не стала заметным явлением, но внесла свой вклад в популяризацию знаний об Арсеньеве. Автор очерка приводит биографию знаменитого путешественника, используя в своем повествовании фрагменты из его произведений.

В это же время, в середине 1950-х гг., предпринимаются первые попытки научного анализа творчества В.К. Арсеньева. В 1954 г. В.К. Путоловой была защищена кандидатская диссертация «В.К. Арсеньев и его литературная деятельность». Оценивая работу Арсеньева с позиций современной ей идеологии, автор исследования утверждает, что только в советское время Владимир Клавдиевич состоялся как писатель и ученый, при этом умаляет его достижения дореволюционного периода: экспедиции в Сихотэ-Алинь, работу в музеях, написание первых трудов. К несомненным достоинствам диссертационной работы следует отнести тот факт, что автор впервые ставит вопрос о жанровой принадлежности трудов Арсеньева, определяя его книги как художественную литературу [22].

Целый ряд публикаций о жизни и деятельности В.К. Арсеньева появились в период 1960-х 1970-х гг. В 1961 г. В. Виноградова ввела в научный оборот несколько неопубликованных ранее материалов о деятельности Арсеньева на Дальнем Востоке [6]. В 1971 г. вышла статья этнографов-лингвистов Л.И. Сем и Ю.А. Сем, в которой впервые была предпринята попытка систематизации экспедиционных дневников и поденных записей путешественника [25]. Серьезную работу по изучению художественного метода Арсеньева провел Владивостокский исследователь Н.В. Старовойтов, опубликовавший в начале 1970-х гг. целый ряд работ [26].

В 1977 г. в издательстве «Советский писатель» вышла книга ленинградского критика И. Кузьмичева, который анализирует литературный стиль Арсеньева и относит его труды к жанру прозы о путешествиях [17]. Несколько публикаций о жизни и деятельности В.К. Арсеньева принадлежат перу хабаровского исследователя Г. Пермякова. В 1960-е - 1970-е гг. он много общался с сыном и первой женой Арсеньева - Владимиром Владимировичем и Анной Константиновной, которые с середины 1950-х гг. жили в Находке. Однако его работы весьма субъективны, и данные, которые он приводит, зачастую неточны или ошибочны [19]. На форзаце его книги «Тропой женьшеня», которая хранится в собрании Музея истории Дальнего
Востока имени В.К. Арсеньева (ранее - Приморский государственный объединенный музея им. В.К. Арсеньева), Владимир Владимирович собственноручно сделал пометку: «Много вранья и отсебятины» (Музей истории Дальнего Востока имени В.К. Арсеньева. МПК 16552/9).

1980-е гг. стали новым этапом в работе с арсеньевским наследием. В постперестроечный период появилось много публикаций, авторами которых были ученые, писатели, журналисты [16; 18; 26]. В 1980 г. в Уссурийске, а в 1984 г. в Хабаровске состоялись научно-практические конференции, посвященные различным аспектам исследовательской деятельности В.К. Арсеньева. С 1987 г. в Приморском государственном музее им. В.К. Арсеньева стали регулярно проходить «Арсеньевские чтения»: исследователи собирались на площадке краевого музея в 1997 , 2000, 2005, 2007, 2012 и 2017 гг. На конференции 1987 г. впервые прозвучал термин «арсениеведение», которым с тех пор стали обозначать весь спектр исследований, связанных с наследием В.К. Арсеньева.

В 1985 г. в серии «Русские путешественники и востоковеды» вышла в свет биография В.К. Арсеньева, составленная научным сотрудником Института Дальнего Востока АН СССР А.И. Тарасовой [28]. Эта книга на несколько десятилетий стала базовым материалом для всех, кто интересовался жизнью и деятельностью известного путешественника. В процессе создания своего труда Тарасова провела большую работу по систематизации наследия В.К. Арсеньева в архивах и музеях страны. Она обработала архив Арсеньева, хранящийся в собрании Приморского филиала РГО, и составила опись, которой пользуются исследователи и в наши дни. В книге есть ряд неточностей и конъюнктурных моментов: слишком много внимания уделяется детским годам исследователя, с упором на его происхождение (отец Владимира Клавдиевича был сыном крепостной крестьянки), в ущерб другим периодам его жизни (в книге, например, совсем не упоминаются «секретные» экспедиции 1911-1913 гг.), необоснованно раздут конфликт В.К. Арсеньева с Н.Н. Гондатти, нет никакой информации о судьбе второй жены и дочери В.К. Арсеньева и т.п. Несмотря на это, книга Тарасовой стала на тот момент наиболее полной биографией В.К. Арсеньева, составленной с привлечением большого круга источников. В 2012 г., к 140-летию со дня рождения В.К. Арсеньева, книга была пере- 
издана по инициативе и на средства ОИАК, но без дополнений и правок [29].

В следующем десятилетии произошли важные для сохранения арсеньевского наследия события: в 1997 г., в канун 125-летия со дня рождения В.К. Арсеньева, был открыт мемориальный музей путешественника во Владивостоке, который стал филиалом краевого музея. В это же время пополняется новыми материалами коллекция В.К. Арсеньева в фонде Приморского государственного музея им. В.К. Арсеньева, и выходит в свет ее сводный каталог. Тогда же, к юбилею путешественника, по инициативе музея был издан памятный альбом «В.К. Арсеньев. Биография в фотографиях, воспоминаниях друзей, свидетельствах эпохи», который является скорее научно-популярным изданием, нежели исследованием. Тем не менее, в ходе его подготовки музейные работники, в сотрудничестве с фотографом Ю. Луганским, провели большую работу, представив на страницах альбома целый ряд впервые опубликованных документов из столичных архивов, относящихся к годам учебы и началу военной службы В.К. Арсеньева [7].

В 1990-е гг. начинает публиковать результаты своих исследований один их ведущих арсениеведов конца XX - начала XXI вв. И.Н. Егорчев [12]. Действительный член географического общества, лауреат премии им. В.К. Арсеньева, он стал редактором и автором вступительных статей к I и II томам академического издания сочинений В.К. Арсеньева, предпринятого издательством «Рубеж» совместно с ОИАК в начале 2000-х гг. Проведя серьезный анализ документов из фондов Российского государственного исторического архива Дальнего Востока, он впервые представил хронологию жизни В.К. Арсеньева в период с 1911 по 1913 гг. и подробно описал его участие в «секретных экспедициях», введя в научный оборот целый ряд неопубликованных ранее источников [11].

В начале 2000-х гг. на базе арсеньевского наследия были подготовлены и защищены три диссертационные работы: диссертация С.В. Гончаровой на соискание ученой степени кандидата исторических наук [9] и две работы филологов - Н.И. Плотниковой и Ю.А. Яроцкой [21; 35]. Литературоведы работали с трудами Арсеньева как с художественными текстами, анализируя способ восприятия мира и стилистические особенности его произведений, а историк С.В. Гончарова в своей диссертации осветила целый ряд вопросов, связанных с деятельно- стью В.К. Арсеньева как геополитика. Рассматривая влияние на его мировоззрение научных концепций рубежа XIX-XX вв., С.В. Гончарова выявляет позицию Арсеньева по вопросам колонизации региона, пишет о прогнозируемых им рисках в развитии территории, связанных с особенностями военно-стратегического положения Дальнего Востока. Автор, таким образом, проанализировал и обобщил взгляды В.К. Арсеньева на вопросы военно-стратегического положения и социально-экономического развития дальневосточной России.

Одной из серьезных работ о В.К. Арсеньеве, опубликованных за последнее время, стала его научная биография, которая вышла в издательстве «Наука» в 2005 г. [31]. Автор книги, владивостокский исследователь А.А. Хисамутдинов, неоднократно публиковал материалы о жизни и деятельности Арсеньева в региональной печати, изучал источники в собраниях архивов и музеев России и зарубежья [32; 33; 34].

Таким образом, очевидно, что многогранная личность В.К. Арсеньева в разные годы вызывала интерес у исследователей, побуждая к переосмыслению и литературному описанию его жизни и деятельности. В то же время современники писателя, участники его экспедиций, стремились оставить воспоминания о нем, описывая непростые обстоятельства походной жизни в тайге. При этом все они анализировали его личность в контексте собственных представлений, опираясь на свой мировоззренческий опыт, сформированный временем и зачастую господствующей идеологией. Однако на рубеже XX-XXI вв., в связи с введением в научный оборот новых источников и появлением в исторической науке нового жанра - интеллектуальной биографии - возникает возможность рассматривать личность В.К. Арсеньева и анализировать его деятельность в широком историческом контексте современных ему событий, идей и научных течений.

\section{СПИСОК ЛИТЕРАТУРЫ}

1. Азадовский М.К. В.К. Арсеньев - путешественник и писатель. Опыт характеристики. Чита: Читинское книжное издательство, 1955.

2. Аристов Ф.Ф. Владимир Клавдиевич Арсеньев (Уссурийский). Фрагменты из исследования // Дальний Восток. 1984. № 9. С. 127-136.

3. Аристов Ф.Ф. Владимир Клавдиевич Арсеньев (Уссурийский) // Землеведение. 1930. Т. 32. Вып. 3-4. С. 208-243. 
4. Аристова Т.В. В.К. Арсеньев вспоминает // Неделя. 1972. № 36. 4-10 сентября.

5. Бордаков П.П. На побережье Японского моря // Юная Россия. 1914. №№ 1-12.

6. Виноградова В. Владимир Клавдиевич Арсеньев: документы о В.К. Арсеньеве // Дальний Восток. 1961. № 1. С. 110-126.

7. Владимир Клавдиевич Арсеньев. Биография в фотографиях, воспоминаниях друзей, свидетельствах эпохи / Сост. Ю. Луганский. Владивосток: Приморский государственный объединенный музей им. В.К. Арсеньева, 1997.

8. Г.В. За большевистскую бдительность в краеведении // Советское краеведение. 1932. № 1. С. 7-17.

9. Гончарова С.В. Исследования В.К. Арсеньева в контексте геополитических проблем Дальнего Востока России: дисс. ... канд. ист. н. Владивосток, 2002.

10. Дзюль И.А. В тайге // Наша охота. Кн. III. СПб., 1910. С. 95-100.

11. Егорчев И.Н. «Согласно личного приказания Вашего высокопревосходительства...» Секретные экспедиции В.К. Арсеньева 19111913 гг. Владивосток: Издательство ДВФУ, 2014.

12. Егорчев И.Н. Тихий юбилей В.К. Арсеньева // Владивосток. 1995. 7 сентября.

13. Ефимов Г. Арсеньев как выразитель великодержавного шовинизма // Красное знамя. 1931. 16 июня.

14. Кабанов Н.Е. Владимир Клавдиевич Арсеньев. Путешественник и натуралист. М.: Издательство Московского общества испытателей природы, 1947.

15. Карпов Г.В. В.К. Арсеньев. М.: Государственное издательство географической литературы, 1955.

16. Кузнецов А. Ученый, писатель, патриот // Красное знамя. 1985. 15 ноября.

17. Кузьмичев И.С. Писатель Арсеньев: личность и книги. Л.: Советский писатель, 1977.

18. Куцый В. Без срока давности // Рыбак Приморья. 1989. 26 мая.

19. Пермяков Г. Тропой женьшеня. Рассказы и очерки о В.К. Арсеньеве. Хабаровск: Хабаровское книжное издательство, 1965.

20. Петрицкий В.А. Неизвестный автограф В.К. Арсеньева (В.К. Арсеньев и М.К. Азадовский) // Страны и народы Востока. М.: Наука, 1979. С. 84-90.

21. Плотникова Н.И. В.К. Арсеньев, творческая индивидуальность писателя: жанровое разнообразие прозы: дисс. ... канд. филол. н. Владивосток, 2003.

22. Путолова В.К. В.К. Арсеньев и его литературная деятельность: дисс. ... канд. филол. н. Л., 1954.

23. Репина Л.П. Личность и общество, или История в биографиях // История через личность. Историческая биография сегодня / Под ред. Л.П. Репиной. М.: Квадрига, 2010. С. 5-16.

24. Рогаль Н.М. В.К. Арсеньев. Историко-биографический очерк. Хабаровск: ОГИЗДАЛЬГИЗ, 1947.

25. Сем Л.И., Сем Ю.А. О «путевых дневниках» и «записных книжках» В.К. Арсеньева // Дальний Восток. 1972. № 8. С. 128-130.

26. Сердюк А. Сопутствовала счастливая звезда // Дальневосточный ученый. 1990. № 8.

27. Старовойтов Н.В. Формирование художественных принципов В.К. Арсеньева и жанровое разнообразие его творчества (ранний период) // Вопросы журналистики и литературы. Владивосток, 1972. С. 128-149.

28. Тарасова А.И. Владимир Клавдиевич Арсеньев. М.: Наука, 1985.

29. Тарасова А.И. Владимир Клавдиевич Арсеньев. Владивосток: Изд. дом Дальневост. федер. ун-та, 2012.

30. Тарасова А.И. К истории первой биографии В.К. Арсеньева // Дальний Восток. 1974. № 9 .

31. Хисамутдинов А.А. Владимир Клавдиевич Арсеньев. М.: Наука, 2005.

32. Хисамутдинов А.А. Переписка двух путешественников. К 125-летию со дня рождения В.К. Арсеньева и Н.А. Байкова // Россияне в Азии. 1998. № 5.

33. Хисамутдинов А.А. По Уссурийскому краю с Дерсу Узала // Владивостокское время. 1995. 14 октября.

34. Хисамутдинов А.А. Последствия одного разговора: неизвестные страницы из жизни В.К. Арсеньева // Тихоокеанский комсомолец. 1988. 30 апреля.

35. Яроцкая Ю.А. Творчество В.К. Арсеньева. Специфика научно-художественной системы: дисс. ... канд. филол. н. Владивосток, 2005.

\section{REFERENCES}

1. Azadovskii, M.K., 1955. V.K. Arsen'ev puteshestvennik i pisatel'. Opyt kharakteristiki [V.K. Arseniev, a traveler and writer. An attempt of characteristic]. Chita: Chitinskoe knizhnoe izdatel'stvo. (in Russ.) 
2. Aristov, F.F., 1984. Vladimir Klavdievich Arsen'ev (Ussuriiskii). Fragmenty iz issledovaniya [Vladimir Klavdievich Arseniev (Ussurisky). Fragments of research], Dalnii Vostok, no. 9, pp. 127-136. (in Russ.)

3. Aristov, F.F., 1930. Vladimir Klavdievich Arsen'ev (Ussuriiskii) [Vladimir Klavdievich Arseniev (Ussurisky)], Zemlevedenie, Vol. 32, no. 3-4, pp. 208-243. (in Russ.)

4. Aristova, T.V., 1972. Arseniev vspominaet [Arseniev remembers], Nedelya, no. 36. (in Russ.)

5. Bordakov, P.P., 1914. Na poberezh'e Yaponskogo morya [On the coast of the Japanese sea], Yunaya Rossiya, no. 1-12. (in Russ.)

6. Vinogradova, V., 1961. Vladimir Klavdievich Arsen'ev: dokumenti o V.K. Arsen'eve [Vladimir Klavdievich Arseniev: documents about V.K. Arseniev], Dal'nii Vostok, no. 1, pp. 110-126. (in Russ.)

7. Luganskii, Yu. ed., 1997. Vladimir Klavdievich Arsen'ev. Biografiya v fotografiyakh, vospominaniyakh druzei, svidetel'stvakh epokhi [Vladimir Klavdievich Arseniev. Biography in photos, memoirs of friends, evidences of the time]. Vladivostok: Primorskii gosudarstvennyi ob'edinennyi muzei im. V.K. Arsen'eva. (in Russ.)

8. G.V., 1932. Za bolshevistskuyu bditel'nost' $\mathrm{v}$ kraevedenii [For the Bolshevik alertness in regional studies], Sovetskoe kraevedenie, no. 1, pp. 7-17. (in Russ.)

9. Goncharova, S.V., 2002. Issledovaniya Arsen'eva v kontekste geopoliticheskikh problem Dal'nego Vostoka Rossii [Arseniev's research in the context of the geopolitical problems of the Russian Far East], dissertatsiya kandidata istoricheskikh nauk. Vladivostok. (in Russ.)

10. Dzyul', I.A., 1910. V taige [In taiga]. In: Nasha okhota. Kn. III. Sankt-Peterburg, pp. 95100. (in Russ.)

11. Egorchev, I.N., 2014. «Soglasno lichnogo prikazaniya Vashego vysokoprevoskhoditel'stva...» Sekretnye ekspeditsii V.K. Arsen'eva 1911-1913 gg. [«By order of your excellency...» The secret expeditions of V.K. Arseniev]. Vladivostok: Izdatel'stvo DVFU. (in Russ.)

12. Egorchev, I.N., 1995. Tikhii yubilei Arsen'eva [Quiet jubilee of Arseniev], Vladivostok, September 7. (in Russ.)

13. Efimov, G., 1931. Arsen'ev kak vyrazitel' velikoderzhavnogo shovinizma [Arseniev as a representative of great-power chauvinism], Krasnoe znamya, June 16. (in Russ.)

14. Kabanov, N.E., 1947. Vladimir Klavdievich Arsen'ev. Puteshestvennik i naturalist [Vladimir
Klavdievich Arseniev, a traveler and naturalist]. Moskva: Izdatel'stvo Moskovskogo obshchestva ispytatelei prirody. (in Russ.)

15. Karpov, G.V., 1955. V.K. Arsen'ev [V.K. Arseniev]. Moskva: Gosudarstvennoe izdatel'stvo geograficheskoi literatury. (in Russ.)

16. Kuznetsov, A., 1985. Uchenyi, pisatel', patriot [Scientist, writer, patriot], Krasnoe znamya, November 15. (in Russ.)

17. Kuz'michev, I.S., 1977. Pisatel' Arsen'ev: lichnost' i knigi [Arseniev as a writer: person and books]. Leningrad: Sovetskii pisatel'. (in Russ.)

18. Kutsyi, V., 1989. Bez sroka davnosti [No statute of limitations], Rybak Primorya, May 26. (in Russ.)

19. Permyakov, G., 1965. Tropoi zhen'shenya. Rasskazy i ocherki o V.K. Arsen'eve [The ginseng trail. Stories and essays about V.K. Arseniev]. Khabarovsk: Khabarovskoe knizhnoe izdatel'stvo. (in Russ.)

20. Petritskii, V.A., 1979. Neizvestnyi avtograf Arsen'eva (V.K. Arseniev i M.K. Azadovskii) [The unknown autograph of Arseniev (V.K. Arseniev and M.K. Azadovskii)]. In: Strany i narody Vostoka. Moskva: Nauka, 1979, pp. 84-90. (in Russ.)

21. Plotnikova, N.I., 2003. V.K. Arsen'ev, tvorcheskaya individual'nost' pisatelya: zhanrovoe raznoobrazie prozy [V.K. Arseniev, the creative personality of the author: genre variety of prose], dissertatsiya kandidata filologicheskikh nauk. Vladivostok. (in Russ.)

22. Putolova, V.K., 1954. V.K. Arsen'ev i ego literaturnaya deyatel'nost' [V.K. Arseniev and his literary work], dissertatsiya kandidata filologicheskikh nauk. Leningrad. (in Russ.)

23. Repina, L.P., 2010. Lichnost' i obshchestvo, ili Istoriya $\mathrm{v}$ biografiyakh [Personality and society, or History in biographies]. In: Repina, L.P. ed., 2010. Istoriya cherez lichnost'. Istoricheskaya biografiya segodnya. Moskva: Kvadriga, pp. 5-16. (in Russ.)

24. Rogal', N.M., 1947. V.K. Arsen'ev. Istorikobiograficheskii ocherk [V.K. Arseniev. Historical and biographical essay]. Khabarovsk: OGIZDAL'GIZ. (in Russ.)

25. Sem, L.I. and Sem, Yu.A., 1972. O «putevykh dnevnikakh» i «zapisnykh knizhkakh» V.K. Arsen'eva [On V.K. Arseniev's road diaries and notebooks], Dalnii Vostok, no. 8, pp. 128-130. (in Russ.)

26. Serdyuk, A., 1990. Soputstvovala shchastlivaya zvezda [Led by lucky star], Dal'nevostochnii uchenii, no. 8. (in Russ.) 
27. Starovoitov, N.V., 1972. Formirovanie khudozhestvennykh printsipov V.K. Arsen'eva i zhanrovoe raznoobrazie ego tvorchestva (rannii period) [The making of V.K. Arseniev's artistic principles and the genre diversity of his work (early period)]. In: Voprosy zhurnalistiki i literatury. Vladivostok, 1972, pp. 128-149. (in Russ.)

28. Tarasova, A.I., 1985. Vladimir Klavdievich Arsen'ev [Vladimir Klavdievich Arseniev]. Moskva: Nauka. (in Russ.)

29. Tarasova, A.I., 2012. Vladimir Klavdievich Arsen'ev [Vladimir Klavdievich Arseniev]. Vladivostok: Izd. dom Dal'nevost. feder. un-ta. (in Russ.)

30. Tarasova, A.I., 1974. K istorii pervoi biografii Arsen'eva [To the history of the first biography of Arseniev], Dalnii Vostok, no. 9. (in Russ.)

31. Khisamutdinov, A.A., 2005. Vladimir Klavdievich Arsen'ev [Vladimir Klavdievich Arseniev]. Moskva: Nauka. (in Russ.)
32. Khisamutdinov, A.A., 1998. Perepiska dvukh puteshestvennikov. K 125-letiyu so dnya rozhdenia V.K. Arsen'eva i N.A. Baikova [The correspondence of two travelers. To the 125th anniversary of V.K. Arseniev and N.A. Baikov], Rossiyane v Azii, no. 5. (in Russ.)

33. Khisamutdinov, A.A., 1995. Po Ussuriiskomu krayu s Dersu Uzala [Across the Ussuri Kray with Dersu Uzala], Vladivostokskoe vremya, October 14. (in Russ.)

34. Khisamutdinov, A.A., 1988. Posledstviya odnogo razgovora: neizvestnye stranitsy iz zhizni V.K. Arsen'eva [The consequences of one conversation: the unknown pages of V.K. Arseniev's life], Tikhookeanskii komsomolets, April 30. (in Russ.)

35. Yarotskaya, Yu.A., 2005. Tvorchestvo V.K. Arsen'eva. Spetsifika nauchno-khudozhestvennoi sistemy [V.K. Arseniev's creative work. The features of research and style], dissertatsiya kandidata filologicheskikh nauk. Vladivostok. (in Russ.)

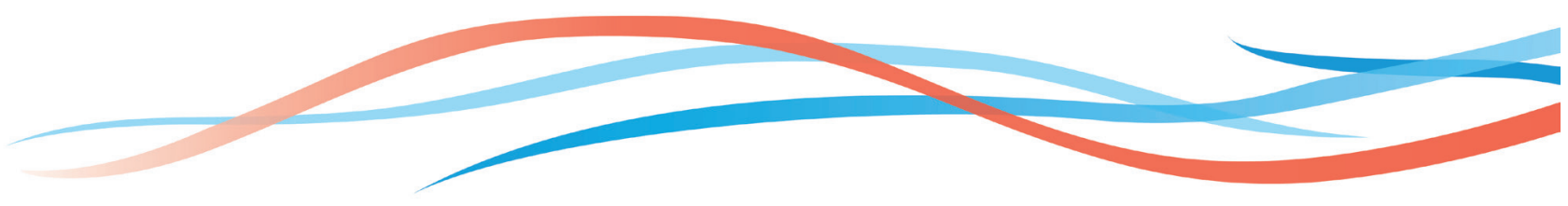

